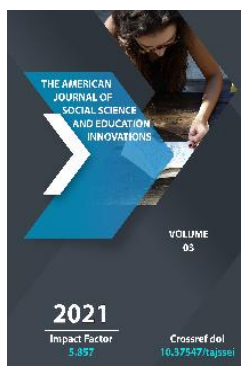

\title{
Study Of Amir Temur 1 And Teshik-Tosh 2 Sites
}

\author{
Lazizbek Amiriddin Ogli O'ngalov \\ Assistant, Samarkand State University, Uzbekistan \\ Abdulla Haydar Ogli Baxronov \\ Assistant, Samarkand State University, Uzbekistan
}

\begin{abstract}
Journal Website:
http://theamericanjour

nals.com/index.php/taj

ssei

Copyright: Original content from this work may be used under the terms of the creative commons attributes 4.0 licence.
\end{abstract}

\section{ABSTRACT}

Uzbek-Russian international archeological expedition, archeological researches in Boysun mountain of Surkhandarya, study of Amir Temur 1 cave of Middle Paleolithic period, study of Teshik-Tash 2 cave of Late Paleolithic period, qualification of material sources found in Middle and Late Paleolithic period.

\section{KEYWORDS}

Amir Temur 1, Teshik-Tosh 2, Machay-Darya, G.V. Parfyonov, A.P. Okladnikov, I.F. Lamaev, Zarautoloshsoy, nuclei, scrapers, drill (spike cannon).

\section{INTRODUCTION}

As a result of research by the Uzbek-Russian international partner expedition, in 2002-2003, an international Uzbek-Russian joint expedition to study the Stone Age in

Uzbekistan conducted research in Boysuntag. As a result, the Amir-Temir 1 cave of the
Middle Paleolithic period and the Teshik-Tash 2 cave of

the Middle and Late Paleolithic period were discovered and studied. The results of these studies have been reflected in a number of articles and scientific reports ${ }^{1}$.

\footnotetext{
${ }^{1}$ Деревянко А.П., Ширинов Т.Ш., Анойкин А.А., Борисов М.А., Гладышев С.А.Исследование грота Тешик-Таш-2 (Республика Узбекистан) // Проблемы археологии, этнографии, антропологии Сибири и сопредельных территорий: Мат-лы Годовой сессии ИАЭт СО РАН 2003 г., посвящ. 95-летию со дня рожА. академика А.П. Окладникова. - Новосибирск: Изд-во ИАЭт СО РАН, 2003. - Т. ІХ, Ч. І. - Р. 101105; Анойкин А.А., Гладышев С.А., Борисов М.А.,
} 
The Boysun Mountains are part of the southwestern ridge of the Gissar Mountains in the Pamir-Alay system and include the southwestern part of Uzbekistan and several regions of neighbouring Tajikistan. The study of the Stone Age in the Machay-Darya, which flows from here, was started by the expedition of the Surkhandarya Museum under the supervision of G.V Parfyonov in 1931. This research lasted four years.

Initially, the Machay Cave was opened, and along with its exploration, the surrounding caves and rocky terraces began to be explored. In 1938-1939, in collaboration with the Surkhandarya Museum, an expedition of the former USSR FA MMTI, led by A.P. Okladnikov, began research in the Teshik-Tash cave, and this year the grave of a Neanderthal boy was found in this cave. At the same time, other caves in the vicinity began to be searched and explored.In his works,A.P. Okladnikov mentioned that in addition to the Teshik-Tash and Machay caves, there are 6 other caves with archeological materials. They also included the Amir-Temir cave, the excavation of which lasted for two years. ${ }^{2}$

Семин А.А. Археологическая разведка в районе хребта Байсун-Тау (Узбекистан). // Проблемы археологии, этнографии, антропологии Сибири и сопредельных территорий: Мат-лы Годовой сессии ИАЭт СО РАН 2003 г., посвящ. 95-летию со дня рожд. академика А.П. Окладникова. Новосибирск: Изд-во Ин-та археологии и этнографии СО РАН, 2003. - Т. ІХ, ч. І. - Р. 1826;Анойкин А.А., Гладышев С.А., Памятники каменного века в горах Байсун-Тау (Узбекистан) // Археология и палеэкология Евразии. - Новосибирск: Изд-во Ин-т археологии и этнографии СО РАН, 2004. -P. 3342:

2 Окладников А.П. Амир-Темир, новый памятник каменного века в горах Байсун-Тау (Узбекистан) ॥ КСИИмК. - 1940. - Вып. 6. - Р. 67-69; Окладников А.П. Исследование мустьерской стоянки и погребения неандертальца в гроте Тешик-Таш, Южный Узбекистан (Средняя Азия) // Тешик-Таш:
World War II forced the suspension of research here, and much of the results obtained remained unpublished.

Hole-stone 2 cave. This object is located about $100 \mathrm{~m}$ above the gorge from the Teshik-tash cave, both monuments are located on the right side of the gorge, at an altitude of 1875 $\mathrm{m}$ above sea level. The tasks of the international expedition in 2002 included stationary excavations at Teshik-Tash 2 cave and additional surveys in the study areas. ${ }^{3}$ Fortunately, A.P. Okladnikov and G.V. It was not possible to find all of the caves mentioned by the Parthians. Nevertheless, the group conducted extensive searches in these areas.

Until 2003, only two monuments, Teshik-Tash and Amir-Temir caves, were known here, as well as published literature. The materials of the hole-stone cave in the form of a monograph and the results of the work carried out in the Amir-Temir cave were published in 1940 in the series "KSIIMK". ${ }^{4}$

The cave is a rocky outcrop extending to $15 \mathrm{~m}$ wide and $61.6 \mathrm{~m}$ long from south to east The floor of the porch is quite sloping and this slope is $25^{\circ}$. The height of the roof is $8-10 \mathrm{~m}$. slightly sloping. Apparently, both karst and gravitational processes were actively involved in filling the cavity inside the cave. On the floor of the cave is a large rock that fell from the roof. Inside, old excavations, the crumbling walls and pits of the trenches can be seen. One of them is located in the

Палеолитический человек.- М.: Изд-во МгУ, 1949. - Р. 7-85.- (Тр.НИИ антропологии);

${ }^{3}$ Деревянко А.П., Ширинов Т.Ш., Анойкин А.А., ${ }^{4}$ Окладников А.П. Амир-Темир, новый памятник каменного века в горах Байсун-Тау (Узбекистан) ॥ КСИИМК. - 1940. - Вып. 6. - Р. 67-69; 
northwestern part of the cave, the other is closer to the central part of the porch. In 2003, excavations of $3 \times 4$ meters were continued by the eastern wall of the pit in the center. The total area of these excavations is 7 $\mathrm{m}^{2}$ and the depth is extended to the rocks at the bottom of the cave, which is $7 \mathrm{~m}$. In general, the porous layers of the Teshik-tash 2 monument (17 stratigraphic horizons are separated) consist of les soils of different shades of brown. ${ }^{5}$ As the cross-section descends, the color of the layers becomes darker and the moisture content increases. In some places there are deposits between the soil layer with gravel and large pieces of limestone. Gravel and soil horizons were formed due to muddy waters that flow seasonally from the cave.

During the excavations, 28 stone objects were collected from the cave. As a raw material, the people who lived here selectively used local limestones, that is, the most siliconized among them. The quality of this raw material is very low and they often have internal cracks, voids and various additives.

In the excavation, stone objects were found in almost all porous layers (layers 2-14) and they have neither stratigraphic nor planigraphic concentration depending on their location. A

\footnotetext{
${ }^{5}$ Деревянко А.П., Ширинов Т.Ш., Анойкин А.А., Борисов М.А., Гладышев С.А.Исследование грота Тешик-Таш-2 (Республика Узбекистан) // Проблемы археологии, этнографии, антропологии Сибири и сопредельных территорий: Мат-лы Годовой сессии ИАЭт СО РАН 2003 г., посвящ. 95-летию со дня рожд. академика А.П. Окладникова. - Новосибирск: ИзА-во ИАЭт СО РАН, 2003. - Т. ІХ, ч. І. - Р. 101105;
}

horizon with a total of 6 materials has been conditionally identified in the monument.

According to the results of the excavations, it can be said that there is no cultural layer in the Teshik-tash 2 monument that is clearly visible. The nature of the artifacts and the conditions of their location do not allow for a planigraphic interpretation of the monument. Apparently, the bulk of the material is close to the hole-stone materials studied by A.P. Okladnikov,that means it belongs to the muste period. At the same time, a series of materials taken from the first horizon of the monument, a straight-shoulder prismatic plate, is reminiscent of Late Paleolithic industries. $^{6}$ Some, separate findings at different depths of the excavation indicate that the cave was repeatedly excavated by primitive people, and that however, these excavations were short-lived, episodic, or seasonal. Apparently, this cave served as a stop for hunters on the transit road from the Gissar ridge to the Machaydarya. Because the shortest route in this direction is through Zarautoloshsoy. The Hole-stone space near the cave was considered more convenient for long-term and long-term living, and this was confirmed by archeological materials.

Amir-Temur 1 cave. This cave is located $2.5 \mathrm{~km}$ west of the village of Upper Machay, in the stream named after Amir Temur $\left(A=273^{\circ}\right)$, its

\footnotetext{
${ }^{6}$ Деревянко А.П., Ширинов Т.Ш., Анойкин А.А., Борисов М.А., Гладышев С.А.Исследование грота Тешик-Таш-2 (Республика Узбекистан) // Проблемы археологии, этнографии, антропологии Сибири и сопредельных территорий: Мат-лы Годовой сессии ИАЭт СО РАН 2003 г., посвящ. 95-летию сО дня рожА. академика А.П. Окладникова. - Новосибирск: Изд-во ИАЭт СО РАН, 2003. - Т. ІХ, Ч. І. - Р. 101105;
} 
absolute height is $1740 \mathrm{~m}$. The cave has a karstic origin and is $70 \mathrm{~m}$ long, $23 \mathrm{~m}$ wide and $3.8 \mathrm{~m}$ high. The mouth of the cave faces northeast. Monument I.F. It was opened by Lamaev and in 1938-1939 A.P. Okladnikov and in 1939 G.V. Studied by Parfenov. ${ }^{7}$ In the 1930s, the total area of excavations here was about $15 \mathrm{~m}^{2}$. The excavations are divided into three cultural strata, two of which are Holocene and the following one is believed to belong to the approximately Muste period (the excavations reached a depth of $1 \mathrm{~m}$ above ground level). Here A.P. Okladnikov's slightly collapsed and north-facing excavation is located in the central part of the cave. Excavations by its eastern wall were expanded to $1 \times 0.5 \mathrm{~m}$ and the excavation depth was increased to $1.9 \mathrm{~m}^{8}$ In general, the porous layers of the Amir-Temir 1 cave (where 7 stratigraphic horizons are separated) consist of lesli soil deposits of different shades of brown. Downstream of the excavation section, the color of the layers becomes darker and the humidity increases.

The excavation deposits are intermittently cut with reddish-brown lens-like layers along their entire thickness, and their composition is

\footnotetext{
${ }^{7}$ Окладников А.П. Амир-Темир, новый памятник каменного века в горах Байсун-Тау (Узбекистан) ॥ КСИИМК. - 1940. - Вып. 6. - С. 67-69; Парфенов Г.В. Каменный период СурханДарьинской области УзССР (по материалам к археологической карте УзССР). - Термез, 1941. (Рукопись, архив Археологического музея г. Термез (Узбекистан), дело № 167. - 23 п.л.);

${ }^{8}$ Анойкин А.А., Гладышев С.А., Борисов М.А., Семин А.А. Археологическая разведка в районе хребта Байсун-Тау (Узбекистан). // Проблемы археологии, этнографии, антропологии Сибири и сопредельных территорий: Мат-лы Годовой сессии ИАЭт СО РАН 2003 г., посвящ. 95-летию со дня рожд. академика А.П. Окладникова. Новосибирск: Изд-во Ин-та археологии и этнографии СО РАН, 2003. - Т. IX, ч. І. - Р. 18-26;
}

similar to that of the base layers. At the bottom of the section there is a layer with sandy and sandy fillings, and its color is gray mixed brown. The folds in the layer are small in size and slightly deflated. In Layer 3 (depth 1 $\mathrm{m}$ above ground level), only $1 \mathrm{~m} 2$ of coal remains were found and a damaged furnace was identified. Several small bone fragments and medium-sized fragments were found in the campfire, which were made of dark siliceous limestone. The tattoo area of the tip is flat and the dorsal negatives are orthogonal.

Cave Amir-Temir 1. In addition to the only find from Cave Amir-Temir 1 in 2003, A.P. 47 stone objects from Okladnikov's excavations are preserved. Of these, 25 are stone fragments, 7 are nucleus-shaped stones, 2 are plates, 7 are fragments, and 6 are stone tools. The stone weapons of the set are made of gallows. All items are made of gray siliceous limestone. The medial portion of the large plate-like incisor in the set has been preserved, and its dorsum is covered with two parallel-shaped negatives, but its shape has a subparallel and irregularly divergent appearance. The large volumes of the collection make up the majority. The rest are medium-sized. The tattoo pads of almost all of these pieces are flat and the tattoo pads of only one are covered with a galvanized shell. The character of the dorsals is parallel or unsystematic in appearance, and one of the dorsals has a primary character.

The set contains 4 nucleus-like fragments and 3 typologically bright nuclei. All cores have a character oriented on longitudinal parallel principles. One of them is rectangular in shape, thin, one-sided, and one-sided. Its back is naturally embossed (size $7.2 \times 5.5 \times 2.8 \mathrm{~cm}$ ). The working surface of the core is almost 
completely covered with a single and large elongated fuel negative. On the right lateral side of the nucleus are two small, elongated, and amorphous fuel negatives, and they are directed toward the working surface of the nucleus. The forging area of the core was formed using a right angle of $80^{\circ}$ and a single large cut. The second core in the set is large, right-angled and triangular in cross section, with two tattoo areas and one work surface (size $40.5 \times 12 \times 7.5$ ). Its tattoo areas are straight, angled at about $80^{\circ}$, and formed using some large angles. The fuels of the nucleus have negatives of different volumes oriented in opposite directions. The working surface of the nucleus is straight and has small lateral flattening negatives directed by its right lateral to the working surface. The back of the core is embossed and partially covered with a shielded shell. The third core of the collection is a tattoo area with two work surfaces. ${ }^{9} \mathrm{It}$ was of medium size and cuboidal and formed using a single cut, the large tattoo area was flat $(6 \times 6.5 \times 6.5 \mathrm{~cm})$. The angle of refraction is close to the right angle. Slightly embossed from the single tattoo area of the nucleus, two right-angled fuels of different sizes were flashed across the surface. This material has a

\footnotetext{
${ }^{9}$ Анойкин А.А., Гладышев С.А., Памятники каменного века в горах Байсун-Тау (Узбекистан) // Археология и палеэкология Евразии. - Новосибирск: Изд-во Ин-т археологии и этнографии СО РАН, 2004. - С. 3342; Анойкин А.А., Гладышев С.А., Борисов М.А., Семин А.А. Археологическая разведка в районе хребта Байсун-Тау (Узбекистан). // Проблемы археологии, этнографии, антропологии Сибири и сопредельных территорий: Мат-лы Годовой сессии ИАЭт СО РАН 2003 г., посвящ. 95-летию со дня рожд. академика А.П. Окладникова. Новосибирск: Изд-во Ин-та археологии и этнографии СО РАН, 2003. - Т. IX, ч. І. - Р. 18-26;
}

proximity to protoprismatic nuclei. its lower narrow part partially retains the galkali shell.

The stone weapons of the Amir-Temir 1 cave consist mainly of destroyers. ${ }^{10}$ One of them is a large double-sided scraper worked longitudinally by the dorsal side, made of a medium-sized, thin, and square-shaped piece of stone. From its two opposite edges, a scraper edge is formed by means of a series of small and medium-sized wide modifier lines, and this edge is supplemented by an additional small and medium-sized lowmodifier edge. dorsally oriented, treated with vertical coin retouches. One of its transverse edges has a flattened and wavy shape using relatively thin double-sided fine and wide grooves. Another scraper weapon is made of a large trapezoidal piece of stone (12.5 $\times 12.5 \times 6$ $\mathrm{cm})$. On one of its edges, a slightly curved cutting edge was formed using small and large-volume modifying lines. This work edge was additionally machined with a series of dorsal-oriented vertical toothed retouches. The two scraper arms in the set are also interesting, and trapezoidal thin galleys were used to make them. ${ }^{11}$ The slightly embossed and narrow edge of one of them was machined using a series of thin grooves of different sizes, resulting in an uneven and $45^{\circ}$ inclined working edge on the beam. The opposite edge of the shield is straight and bold.

\footnotetext{
${ }^{10}$ Shown literature. - Р. 38;

${ }^{11}$ Анойкин А.А., Гладышев С.А., Памятники каменного века в горах Байсун-Тау (Узбекистан) // Археология и палеэкология Евразии. - Новосибирск: ИзА-во Ин-т археологии и этнографии СО РАН, 2004. - Р. 3342;
} 
The set also includes a scraper made of three parts of a medium-sized and rectangular piece of stone. This stone weapon can be included in the list of macros. In addition, the AmirTemir 1 industry also has a single piercing ((spike cannon) weapon. It is made of large and thin trapezoidal natural fibers. Its relatively longer natural triangular angle series is machined using opposite, fine, and wide modification lines; their negatives are successive, they form a large and round bulge, and this bulge has irregular marks left over from its use.

\section{REFERENCES}

1. Окладников А.П. Амир-Темир, новый памятник каменного века в горах Байсун-Тау (Узбекистан) \/ КСИИМК. 1940. - Вып. 6. - С. 67-69;

2. Окладников А.П. Исследование мустьерской стоянки и погребения неандертальца в гроте Тешик-Таш, Южный Узбекистан (Средняя Азия) // Тешик-Таш: Палеолитический человек. М.: Изд-во МГУ, 1949. - С. 7-85. - (Тр.НИИ антропологии).

3. Парфенов Г.В. Каменный период Сурхан-Дарьинской области УзССР (по материалам к археологической карте УзССР). - Термез, 1941. -(Рукопись, архив Археологического музея г. Термез (Узбекистан), дело № 167. - 23 п.л.).

4. Анойкин А.А., Гладышев С.А., Борисов М.А., Семин А.А. Археологическая разведка в районе хребта Байсун-Тау (Узбекистан). // Проблемы археологии, этнографии, антропологии Сибири и сопредельных территорий: Мат-лы ГОДОВОЙ СесСИИ ИАЭТ СО РАН 2003 Г., посвящ. 95-летию со дня рожА. академика А.П. Окладникова. Новосибирск: Изд-во Ин-та археологии и этнографии СО РАН, 2003. - Т. IX, ч. І. С. 18-26.

5. Анойкин А.А., Гладышев С.А., Памятники каменного века в горах Байсун-Тау (Узбекистан) // Археология и палеэкология Евразии. - Новосибирск: Изд-во Ин-т археологии и этнографии СО РAH, 2004. - С. 33-42.

6. Деревянко А.П., Ширинов Т.Ш., Анойкин А.А., Борисов М.А., Гладышев С.А. Исследование грота Тешик-Таш-2 (Республика Узбекистан) // Проблемы археологии, этнографии, антропологии Сибири и сопредельных территорий: Мат-лы Годовой сессии ИАЭт СО РАН 2003 г., посвящ. 95-летию со дня рожд. академика А.П. Окладникова. Новосибирск: Изд-во ИАЭт СО РАН, 2003. - T. IX, ч. I. - C. 101-105. 